\title{
Unpopular Sovereignty: Mormons and the Federal Management of Early Utah Territory
}

Review Number: 2170

Publish date: Thursday, 21 September, 2017

Author: Brent M. Rogers

ISBN: 9780803295858

Date of Publication: 2017

Price: $£ 54.00$

Pages: 402pp.

Publisher: University of Nebraska Press

Publisher url: http://www.nebraskapress.unl.edu/university-of-nebraska-press/9780803276772/

Place of Publication: Lincoln, NE

Reviewer: James Williamson

19th-century America is increasingly seen as a nation coming to terms with central state authority as a mechanism to support its expansionist ambitions. Historians such as Heather Cox Richardson and Steven Hahn have recast the period from the 1850s through to the end of the 19th century as one in which a political elite, situated in the northeast, was able to gradually extend its influence across the nation, militarily, culturally and economically.(1) One group which is well-suited for consideration in relation to this burgeoning field are members of the Church of Jesus Christ of Latter-day Saints. Throughout the 19th century, Church members struggled with their relationship with various national and state government administrations and, once gathered in Utah, used their demographic advantage to try and protect their own distinctive religious and social practices from what they perceived to be an oppressive and corrupt federal government. In recent years, Mormon historiography, for so long an insular field concerned with protecting the Church's image, has entered into mainstream historical discourse. The status of Latter-day Saints, as American citizens existing on the fringes of the nation both geographically and philosophically, makes them particularly useful for gaining an insight into dominant themes or values within American society. Recent works have used the status of Mormonism within 19th-century America to inform our understanding of constitutional interpretations of marriage, conceptions of public and private spheres and racial 'othering' as a bar to the protections of citizenship. $(2)$

There was certainly a gap within the historiography to consider the Mormon experience in Utah in relation to the new historiography of a quasi-imperialistic American central state. When the West has been used a theatre for these sorts of analyses, the focus has more often been upon Native Americans, who can more easily be seen as victims of an expanding 'national' authority. However, there is just as much scope to address how white Americans interacted with, and opposed, federal authority in the West. In his first full publication, Unpopular Sovereignty, Brent Rogers brings these debates to Utah, masterfully combining these two current trends within the historiography of the United States in order to make a comment upon debates over 'popular sovereignty' in antebellum America. Whilst less concerned perhaps with ideas of imperial culture, he does demonstrate how the Mormon Question in the 1850s helped Americans to reconcile themselves to the expansion of central state authority over the American people. 
The central claim of Rogers's book is that our understanding of popular sovereignty has been too closely confined to sectional debates over slavery. This is not to ignore slavery's significant contribution to the emergence of the concept, which argued for the right of individual states and territories to make their own political decisions rather than be beholden to the decisions of the Federal Government. Popular sovereignty was intrinsically tied up in debates over the role of slavery in the western expansion of the United States. Rather, Rogers's point is that the idea also had repercussions within other aspects of American politics, which served to further muddle discourse over the relationship between the Federal Government, individual states and western territories. Whilst popular sovereignty was borne from the problem of slavery in the American West, it created a wider legacy in which Americans grappled with the tension between democratic sentiment within territories and the desire to form correct models of republican government, loyal to the values of the nation. The Mormon question caused political figures, particularly within the Democratic Party, to interrogate within themselves the extent to which they were willing to follow the mantra of local self-government.

To demonstrate the ways in which conflicts over sovereignty operated within Utah, Rogers chooses three different areas of analysis. The first of these covers competing interpretations of republicanism - how Latterday Saints and territorial officials differed in their understanding of how a republican government which best represented the interests of its population could be implemented. The second deals with the relationship between the LDS Church and the local indigenous population. The centrality of the 'Lamanite' figure within Mormon theology meant that the Church operated a very different policy towards the Native American population than many other Americans, leading to accusations that the Church was conspiring with Native Americans in a plot to overthrow federal authority within the region. The third source of conflict stemmed from gender relations, in particular the threat that federal soldiers stationed in Utah posed to the stability of polygamous marriages within the territory. So central were women and polygamy to the Church's understanding of a strong religious community that the advances of non-Mormons soldiers towards Mormon women was considered an affront to Church sovereignty within Utah. In each of these instances, Utah Mormons demonstrated a unique aspect to life in their territory and asserted their right to organise their lives how they best saw fit. Within national discourse such actions were attacked as the work of a seditious group rejecting the values of the nation and the authority of the Federal Government. Meanwhile, the response of federal or territorial officials trying to curb Mormon peculiarities met with criticism from Latter-day Saints who believed they were simply acting within their constitutional rights. These three different arenas of debate are presented as distinct issues within the first half of the book, before coalescing in the second half in order to demonstrate the debates which led to the Utah Expedition of 1857, in which President James Buchanan sent federal troops to remove Church President Brigham Young as Governor of the Territory.

Rogers's analysis of debates over popular sovereignty operates on two levels. On the local level, he identifies a Mormon leadership which invoked an alternative interpretation of republicanism and a long history of persecution by state governments in order to argue that they were well within their constitutional rights to claim local autonomy and the right to form their own government. Latter-day Saints, led by Brigham Young, co-opted the language of popular sovereignty used by the Democratic Party in order to assert their own right to practice polygamy and organise a territorial government built upon Church values, free from molestation from the Federal Government. Whilst Utah, as a territory, was technically a ward of the national government, firmly within federal jurisdiction, the Church drew upon mainstream political sentiment in favour of localised political decision-making to try and secure the same kind of authority that had been used to persecute them in their previous settlements in the east.

On the national level, Rogers turn this analysis around, showing how the Mormon question served to confuse and alter the ways in which both major political parties of the late 1850s understood the machinations of popular sovereignty. Over the issue of slavery, the distinction between the Republican and Democratic parties was clear. The Republicans rejected the mantra of popular sovereignty, invoking the 
Northwest Ordinance to claim the right of the Federal Government to root out the 'twin relics of barbarism', polygamy and slavery. The Democrats, embracing the idea first introduced by Stephen Douglas, asserted that residents of western territories should be able to make their own decision on whether slavery would exist within their borders. However, as public sentiment became increasingly hostile towards the Latter-day Saints, fuelled by sensationalist accounts in the press and incendiary reports from territorial officials, the Democratic administration, led by President Buchanan, came under pressure to take a strong stance against the Mormon Church. Whilst such a move may have been popular on the face of it, to intervene in Utah and enforce change upon the Mormon population represented a violation of popular sovereignty. Buchanan would eventually intervene in Utah, despite the claims of Latter-day Saints that they were simply exercising the same rights to local self-government that the Democrats themselves sought in relation to slavery. Buchanan's intervention, while effective in dealing with the Mormons, was a death knell for popular sovereignty, allowing the Republicans to claim that it had only ever been a lame justification for the protection of slavery. By showing how popular sovereignty operated as a term beyond simply questions of slavery, Rogers is able to better inform our understanding of how Americans grappled with the relationship of the central state to its constituent members and wards.

One small aside is that Rogers's account of the political quandary that Utah posed to the Democratic Party makes the decision of Buchanan to send troops to Utah much more logical than it often seems in many other accounts of the Utah Expedition. Often the war is presented as a confusing, premature response by the President, a desperate attempt to assert his authority or a misled endeavour brought on by lying federal officials. Rogers does a better job than most in situating the decision within the contemporary political context.

One area which perhaps could have benefitted from greater clarity from the author is his decision for the endpoint of the book. Rogers's account culminates with the 1862 Morrill Anti-Bigamy Act, which prohibited polygamy in federal territories. Rogers presents the passage of this law as the culmination of the Federal Government's attempts to assert its right to regulate its territories, putting the issue of popular sovereignty as a defence to bed once and for all. The fact that such a law was able to pass Congress demonstrates that the rights of the inhabitants of territories to invoke popular sovereignty in defence of unpopular local practices had fallen to the wayside. However, what is notable is that the Morrill Act, despite the legitimacy that it bestowed upon federal officials to intervene in Utah, was effectively unenforceable. The sheer weight of numbers that the Latter-day Saints enjoyed in Utah, and the prominence of Church leaders within local politics meant that polygamy convictions were impossible to achieve within Utah for over 20 years.

There were certainly a number of contingency factors that got in the way of effective enforcement of the Morrill Act throughout those two decades - Civil War necessities, the political agendas of Democrats who continued to oppose strong federal intervention - but the fact remains that the supposed federal superiority that Rogers establishes at the end of his book did not translate into any kind of strong presence on the ground. This may fall into the classic scenario of a reviewer commenting upon an issue which does not fall within the remit that the author set themselves; Unpopular Sovereignty focusses upon popular sovereignty within antebellum America and the continued defiance of the Latter-day Saints marked the three decades after which this book concerns itself. Rogers is aware though of the ongoing difficulties that federal officials faced in securing polygamy convictions after 1862. He mentions them within the final pages of his book, but only in passing, across two pages of his final chapter. This is also not a criticism of Rogers's main argument either, or the quality of the work that he has produced. His book draws upon an extensive understanding of the historiography of the Latter-day Saints and of political understanding of government authority, along with a rich base of source material to show conclusively that Utah was significant to debates over popular sovereignty. However, when assessing the significance of political ideas it is perhaps just as useful to see how they were implemented as to just focus on their symbolic value within national politics. Whilst popular sovereignty may have lost its lustre as a political rallying cry by 1860 , the Utah question is just as useful to historians for the ways in which it shows the continued weight that was attached to the rights of autonomous communities to form their own political and social institutions. Legislation may have been passed which 
asserted the right of the Federal Government to regulate marital practices in Utah, but this legitimising language never resulted in firm action. So powerful did this sentiment towards local self-government remain within the national mindset that Utah Mormons, overwhelmingly unpopular with members of both the Democratic and Republican parties, were able to exploit it to openly defy federal law until the 1880s. Some greater anecdotal evidence from the author about how the 'triumph of nationalism over local rights' (p. 290) communicated with a long-standing lived tradition of local sovereignty would have provided a greater degree of illumination to the conclusion of a very impressive piece of historical writing.

Despite this, that so many words of this review have been devoted to what is effectively a question mark over chronology speaks to the overall quality of publication that Rogers has produced. Any historian seeking to more fully understand debates over sovereignty or the relationship between federal and local governments within antebellum America should consult this work.

\section{Notes}

1. Heather Cox Richardson, West From Appomattox: The Reconstruction of America After the Civil War (New Haven, CT, 2007); Steven Hahn, A Nation Without Borders: The United States and its World in an Age of Civil Wars, 1830-1910 (New York, NY, 2016). See also The World the Civil War Made, ed. Gregory Downs and Kate Masur (Chapel Hill, NC, 2015).Back to (1)

2. Sarah Barringer Gordon, The Mormon Question: Polygamy and Constitutional Conflict in Nineteenthcentury America, (Chapel Hill, NC, 2002); Christine Talbot, A Foreign Kingdom: Mormons and Polygamy in American Political Culture, 1852-1890, (Chicago, IL, 2013); W. Paul Reeve, Religion of a Different Color: Race and the Mormon Struggle for Whiteness, (New York, NY, 2015).Back to (2)

Source URL:https://reviews.history.ac.uk/review/2170

\section{Links}

[1] https://reviews.history.ac.uk/item/267818 